\title{
On Frantz Fanon: Key Concepts
}

\section{Sara Farban}

\section{Introduction}

Frantz Fanon (1925-1961) was a Martinique-born psychiatrist, theorist, philosopher, playwright, and a leading political actor and figure in the struggle for decolonization. Between the publication of his two best-known works, Black Skin, White Masks (Peau noire, masques blancs, 1952) and The Wretched of the Earth (Les damnés de la terre, 1961), Fanon defended his medical thesis in Paris and was a resident psychiatrist at the Blida-Joinville Hospital in Algeria. He also published several more books and numerous clinical and critical articles advancing counter-narratives on colonialism and colonial psychiatry in various medical and radical journals. In the following decades, his work became canonical in postcolonial studies and has shaped the common parlance of scholarship on the Global South. This vignette showcases Fanon's contribution through an examination of his most prevalent scholarship and theories, and a brief summary of his influence on decolonization studies.

\section{Fanon's Prevalent Work: Influences and Epistemological Shifts}

From Black Skin, White Masks onward, Fanon's work was in dialogue with Négritude, the 1930s and 1940s French anticolonial literary movement that critiqued white domination and rationalization of black emotions, cultural identity, language, and mentalité. ${ }^{1}$ Fanon employs the terminology of Négritude to promote the universality of the experience of oppression and to contextualize the psychology of dehumanization, racism, and oppression inherent in colonialism, and its impact on the conceptualization of identity. ${ }^{2}$ Yet Fanon's relationship with Négritude was complex and ambivalent, as he often viewed the movement's leaders as "men of culture" who reinforced the colonial practices they criticized. ${ }^{3}$ In this regard, Fanon's work is an example of the epistemic shifts and the evolutions within philosophies on decolonization.

In underscoring the intricacies of emancipatory social change and national liberation struggles in colonial contexts, Fanon's humanist, anti-racist, and anti-capitalist writings call for an internationalist vision of decolonization. ${ }^{4}$ His work draws attention to the impact of oppression on the outward expression of the self in relation to peers, institutions, and societies. The birth and rebirth of the "new man" links the human experience and the denial of selfhood to the universality of colonialism. ${ }^{5}$ Fanon is therefore critical of Freudian psychoanalysis for its reduction of colonial oppression to isolated occurrences. ${ }^{6}$ The experiences of dehumanization transcend the individual, as it constitutes a "massive psychoexistential complex" driven by the systemic dehumanization inherent in colonialism. ${ }^{7}$ Fanon's universalist ap- 
proach has shaped decolonization frameworks and continues to inform the emancipatory vernacular of popular movements in the Global South.

Black Skin, White Masks, Fanon's first book, examines how race, language, and culture shape the self-perception of colonized subjects. The colonized attempts to access white culture through assimilation, but the racialization process prevents full integration, and creates "an inferiority complex" that exists as an "outcome of a double process: primarily economic, subsequently, the internalisation, or better, the epidermalisation —of this inferiority." 8 This hybridity is a counter-hegemonic oppositional force to colonial practices, a non-assimilationist modality of connection-building across cultures.

Published just before Fanon's death, The Wretched of the Earth emphasizes the universality of oppression. ${ }^{9}$ In critiquing imperialism and nationalism, Fanon asserts the psychological impact of dehumanization: the "triumph [of] colonization [is] a constant and considerable stream of mental symptoms." ${ }^{10}$ Colonial pogroms psychologically shape the colonized subject's behaviour in relation to the colonizer. In highlighting the universality of oppression, Fanon calls for the inclusion and participation of all aspects of colonized societies in the revolutionary struggle. The $W$ retched of the Earth underscores the urgency of generational struggle against imperialism, for "independence is inevitable and automatically inscribed in the people's consciousness." Here Fanon highlights the limitations of nationalism. He urges for a consciousness beyond national borders and toward a universal recognition of oppression.

The essays and articles Fanon wrote between the above-mentioned works are collected in two posthumous publications: Toward the African Revolution (Pour la révolution africaine, 1964), and Alienation and Freedom (2015). These collections highlight the genesis and development of Fanon's theories, particularly the evolution of concepts noted in A Dying Colonialism (1959) and The Wretched of the Earth. Fanon's theories were shaped by his personal experiences. His observation and assessment of five bloody years of the Algerian struggle against French colonialism constituted L'An V de la révolution algérienne (1959). Republished in 1967 as A Dying Colonialism, the text details the colonized subject's responses to dehumanization, exploitation, and suffering at the hands of brutal imperial oppressors. The work is a philosophical and political enquiry into how social forces resist colonial pogroms. Although $A$ Dying Colonialism presents Algerians as a monolithic entity, the shared struggle against the French forged a "unified experience and gave it a universal dimension." 12 In highlighting the employment of culture derided by the colonizer, Fanon underscores how nearly all aspects of Algerians' lives and routines, gender and family dynamics, as well as medical practices were in and of themselves a form of resistance.

\section{Fanonian Humanism}

Fanon's anti-colonial, universal humanism rejects cultural assimilation. He suggests that popular struggles open the possibility for mass rejection of colonialism and 
daily practices of racial oppression. This is one of the fundamental bases of Fanonian humanism. ${ }^{13}$ He differentiates this humanism from Euro-centric understandings of culture and civilization, and underlines the consciousness of the colonized subject as a means of reclaiming human dignity and the conceptualization of selfhood within anti-colonial struggle. Formerly colonized subjects "must start over a new history of man," one that acknowledges European domination of historical narratives as well as "its crimes, the most heinous of which have been committed at the very heart of man, the pathological dismembering of his functions and the erosion of his unity." 14 As the colonized reclaim their sense of self, contrary to the dehumanized identity imposed onto them by the colonizer, they face a process of alienation wherein they are rejected not only by the dominant culture but also by their culturally assimilated peers. ${ }^{15}$ In short, Fanon asserts that it is the psychological colonization of identities that imposes deformed self-consciousness of the colonized subject within and outside of their communities. It is through universal humanism that colonized communities can become self-conscious and move toward liberation.

\section{Fanon on Hegel and Marx}

Fanon challenges Hegelian consciousness, which is defined within labour relations as the condition of existence. When post-war France underwent a Hegelian revival, Fanon negated Hegel's "Lordship and Bondage" paradigm postured in Phenomenology of Mind. While Hegel suggests that lack of reciprocal recognition between the slave and his master leads to the alienation of labour within capitalist social relations, Fanon contends that slaves are identified not only through their labour but also their race. ${ }^{16}$ Specifically, race dictates roles in labour relations, as identity becomes a source of dehumanization expressed in an "open conflict between black and white." 17 The part of an identity which experiences dehumanization, i.e. race and culture, must be amplified in labour relations critique. ${ }^{18}$ In social labour relations, the colonizer's identity does not require recognition by the colonized. It is the colonized who depends on the colonizer to affirm their humanity through recognition. ${ }^{19}$

Fanon's observation and analysis of labour relations during the Algerian War of Independence (1954-1962) suggest that the peasantry and the urban lumpenproletariat - the lower-strata labour force that is not particularly interested in or conscious of their own revolutionary capabilities — can constitute a revolutionary force. This assertion directly challenges Marx's assertion in Eighteenth Brumaire, that the proletariat is a driving force in history while the lumpenproletariat and the peasantry are counter-revolutionary. ${ }^{20}$ Fanon reaffirms Marx's claim that colonial institutions and the treacherous indigenous bourgeoisie work together to erode class-cohesion. However, he observes that in diagnosing lumpenproletariat youth as juvenile delinquents, the colonial structure flexes its institutional prowess to undermine the revolutionary potential of this cadre. ${ }^{21}$ Fanon showcases a racial dimension to the 
contradictions emerging within colonial societies that extend beyond the bourgeoisie/proletariat divide noted in Eighteenth Brumaire. ${ }^{22} \mathrm{He}$ asserts that decolonization is not simply the redistribution of wealth, but a psychological reframing of the colonized mind that forms a "new man." This decolonized psychology reconstructs a sense of self, which helps with the recovery process of the trauma of dehumanization.

\section{On Gender and Violence}

The reconstruction of selfhood employs cultural practices that directly oppose colonial governance. The colonizer monopolizes violence and reframes gender to justify persistent interventionism. However, Fanon's assessment of violence and gender as categories of analysis of colonial and anti-colonial processes has received mixed responses from scholars. In describing forms of resistance, Fanon showcases how gender inevitably becomes a site of anticolonial struggle. The colonizer perceives colonized women as the epitome of stillness and backwardness, and their emancipation and role in society become sites of contestation. In discussing the experiences of Algerian women, Fanon examines the historical dynamism of the veil noted in orientalist motifs. ${ }^{23}$ The "veil removed and reassumed again and again," becomes an ornament of contestation, "manipulated and transformed into a technique of camouflage, into a means of struggle." 24 The veil-and therefore, women-becomes essential to the articulation of decolonized identities. In direct response to, and mobilization against, colonialism, a "new dialect of the body" emerges wherein "the veil helped the Algerian woman to meet the new problems created by the struggle." 25 In unveiling the Algerian woman, the colonizer attempts to detach her away from her society, thus undermining struggles of resistance. But, the Algerian woman senses the underlying themes within this equation and clings to the veil as an act of resistance. ${ }^{26}$ Therefore, as patriarchal structures were challenged by national liberation struggles, women were not only the site of these manifestations but central actors in the resistance. The patriarchal tropes that characterize Fanon's work, and the questions he fails to ask, have been critiqued by radical feminist scholarship. ${ }^{27}$ Yet it is important to recognize that Fanon interrogates gender dynamics in the colonial context and showcases women's centrality in revolutionary experiences. ${ }^{28}$

As Fanon highlights the gendered responses to colonial domination, he also considers the monopolization of violence as a feature of colonialism. To Fanon, the manifestation of violence within anticolonial struggles is necessary, since violence itself is a fundamental component of colonialism. ${ }^{29}$ As Jean-Paul Sartre asserts in the preface to The Wretched of the Earth, "how come [the colonizer] can't see his own savagery as a colonist in the savagery of these oppressed peasants who have absorbed it through every pore and for which they can find no cure?" To undo this trauma, decolonization requires "constant acts of repeated aggression ... which sooner or later the European will have to pay for." ${ }^{30}$ When Fanon posits, "the 
colonised man finds his freedom in and through violence," he is suggesting that the counter-violence of the colonized is a practical response to colonial violence. ${ }^{31}$ The psychopathology of violence emerges out of reciprocal social relations that are exacerbated by the sadomasochistic nature of colonial institutions. The struggle for decolonization "should not ... be treated as the same as the colonizers' violence (which is the maintenance of colonialism)." 32

\section{On the Global South}

In reflecting on the process of dehumanization and re-examining the question of humanity, Global South scholarship has embraced Fanonian universalism. Edward Said's groundbreaking work Orientalism narrates the historical articulation of the wretchedness, i.e. othering, of the Orient within the conceptualization of colonial identities. ${ }^{33}$ Similarly, Towards an African Revolution influenced the works of Brazilian decolonization scholar, Paulo Freire, who engages with Fanonian Humanism to theorize that rather than dismantling the capitalist structure, indigenous elite seek to replace the role of the colonizer in social and labour relations. ${ }^{34}$ In rejecting Eurocentrism and embracing the universality of colonial oppression, postcolonial and Global South scholarship continues to heed Fanon's call: "let us flee this stagnation where dialectics has gradually turned into a logic of status quo. Let us re-examine the question of man ... for ourselves and for humanity, comrades, we must make a new start, develop a new way of thinking, and endeavour to create a new man." ${ }^{35}$ 


\section{NOTES}

${ }^{1}$ Irene L. Gendzier, Frantr. Fanon: A Critical Study (New York: Pantheon, 1973); Reiland Rabaka, The Negritude Movement: W.E.B. Du Bois, Leon Damas, Aime Cesaire, Leopold Senghor, Frantz. Fanon, and the Evolution of an Insurgent Idea (London: Rowman and Littlefield International, 2015), 326.

2 Peter Hudis, Frantz Fanon: Philosopher of the Barricades (London: Pluto Press, 2015), 49-53.

${ }^{3}$ Azzedine Haddour, "Sartre and Fanon: On Negritude and Political Participation," Sartre Studies International 11, no. 2 (2005): 286.

${ }^{4}$ Leo Zeilig, Frantr. Fanon: The Militant Philosopher of the Third World Revolution (New York: I.B. Tauris, 2016), 72, 247.

${ }^{5}$ Marilyn Nissim-Sabat, "Fanonian Musings: Decolonizing/Philosophy/Psychiatry," in Fanon and the Decolonization of Philosophy, ed. Elizabeth A. Hoppe and Tracey Nicholls (London: Rowman and Littlefield International, 2010), 51.

${ }^{6}$ Nigel Gibson, Fanon: The Postcolonial Imagination (Oxford: Blackwell Publishers, 2017), 9.

${ }^{7}$ Frantz Fanon, Black Skin, White Masks, trans. Charles Lam Markmann (New York: Grove Press, 1967), 12.

${ }^{8}$ Fanon, Black Skin, White Masks, 11.

${ }^{9}$ Christopher J. Lee, Frantz Fanon: Toward a Revolutionary Humanism (Athens, OH: Ohio University Press, 2015), 28, 146-147.

${ }^{10}$ Frantz Fanon, The Wretched of the Earth, trans. Constance Farrington (New York: Grove Press, 1965), 182.

${ }^{11}$ Fanon, The Wretched of the Earth, 179.

${ }^{12}$ Frantz Fanon, A Dying Colonialism, trans. Haakon Chevalier (New York: Grove Press, 1965), 89.

${ }^{13}$ Nigel Gibson, Fanon: The Postcolonial Imagination (Oxford: Blackwell Publishers, 2003),181.

${ }^{14}$ Fanon, The Wretched of the Earth, 238.

${ }^{15}$ Hudis, 119.

${ }^{16}$ Fredrich Hegel, The Phenomenology of Mind, trans. George Lichtheim (New York: Harper \& Row, 1967), 231.

${ }^{17}$ Fanon, Black Skin, White Masks, 231.

${ }^{18}$ Robert R. Williams, Hegel's Ethics of Recognition (Los Angeles: University of California Press, 1997), 49.

${ }^{19}$ Fanon, Black Skin, White Masks, 218.

${ }^{20}$ Karl Marx, The Eighteenth Brumaire of Louis Bonaparte, trans. Friedrich Engels and 
Saul K. Padover (Moscow: Progress Publishers,1937), 33.

${ }^{21}$ Frantz Fanon, The Wretched of the Earth, 81.

22 Ibid., 128

${ }^{23}$ Ian Buruma and Acishai Margalit, Occidentalism: The West in the Eyes of its Enemies (Toronto: Penguin Books, 2005), 131.

${ }^{24}$ Fanon, A Dying Colonialism, 61.

${ }^{25}$ Ibid., 59-63.

${ }^{26}$ Sophie Bélot, "The Algerian Woman in Conflict in The Battle of Algiers (Gillo Pontecorvo, 1966)," in Algeria Revisited: History, Culture, and Identity, ed. Rabah Aissaoui and Claire Eldridge (New York: Bloomsbury, 2017), 176.

${ }^{27}$ Madhu Dubey, “The 'true lie' of the nation: Fanon and feminism," Differences: A Journal of Feminist Cultural Studies 10, no. 2 (1998): 131.

${ }^{28}$ Fanon, A Dying Colonialism, 35-63.

${ }^{29}$ Fanon, The Wretched of the Earth, 23.

${ }^{30}$ Jean-Paul Sartre, "Foreward," in Fanon, The Wretched of the Earth, li.

${ }^{31}$ Fanon, The Wretched of the Earth, 86

${ }^{32}$ Lewis Ricardo Gordon, What Fanon Said: A Philosophical Introduction to his Life and Thought (New York: Fordham University Press, 1996), 306.

${ }^{33}$ Edward Said, Orientalism (New York: Pantheon Books, 1978), 124.

${ }^{34}$ Paulo Freire, Pedagogy of the Oppressed, trans. Myra Ramos (New York: Herder and Herder, 1970).

${ }^{35}$ Fanon, The Wretched of the Earth, 237-239. 